\title{
ARHGAP11B wt Allele
}

National Cancer Institute

\section{Source}

National Cancer Institute. ARHGAP11B wt Allele. NCI Thesaurus. Code C125466.

Human ARHGAP11B wild-type allele is located in the vicinity of 15q13.2 and is

approximately $149 \mathrm{~kb}$ in length. This allele, which encodes Rho GTPase-activating protein

$11 \mathrm{~B}$, plays a role in both signal transduction and brain cortex development. 